\title{
Relationship between Smoking and Hypertension in Patients with Stroke
}

\author{
Cut Aria Arina ${ }^{1}$, Cut Aryfa Andra ${ }^{2}$ \\ ${ }^{1}$ Department of Neurology, Medical Faculty, University of Sumatera Utara, Indonesia \\ ariaarina2010@gmail.com \\ ${ }^{2}$ Department of Cardiology, Medical Faculty, University of Sumatera Utara, Indonesia \\ andra1711@gmail.com
}

\begin{abstract}
Smoking and hypertension have an important role in mechanism of stroke, both of it also act as major risk factor of stroke. The purpose of this study was to know the relation between smoking and hypertension in patients with stroke. This study is a cross sectional study, the sample was taken consecutively. All sample matched with inclusion and exclusion criteria, demography data and blood sample were taken. Demography data was analized using descriptive statistic, to analize the relationship, we used Chi-Square test. $P$ value $<0,05$ was significant. From the total of 100 patients, the 68 patients had ischaemic stroke and 32 patients had haemorrhagic stroke, smoker 62 patients (45 ischaemic stroke, 17 haemorrhagic stroke), hypertension 79 patients (51 ischaemic stroke, 28 haemorrhagic stroke). There is a significant relationship between smoking and hypertension, $p$ value $=0,001$. Significant relationship between smoking and hypertension might be because both of its have an important role in developing of atherosclerotic vascular disease.
\end{abstract}

Keywords - smoking, hypertension, ischaemic stroke, haemorrhagic stroke, atherosclerotic.

\section{INTRODUCTION}

Stroke remains as main health problem in many countries in the world, stroke is the third most common cause of death after cardiovascular disease and cancer. Almost $3 / 4$ million people in USA had stroke every year, and 150.000 death due to stroke (woman:man = 3:2) [1], [2], [3].

Basic Health research Indonesia (Riskesdas) 2013 mention that stroke remains the most common of death, at aged 45-54 (15,9\%) and at aged 55- 64 $(26 \%)$. [4] Smoking and hypertension have an important role in mechanism of stroke, both of it also act as major risk factor for all type of stroke which has role for disability and death. [5]

Population study consist of many ethnics showed that there is a strong relation between smoking and stroke, where as smoking had increasing risk of stroke about two until four times compared with non smoker or individu that quit smoking for more than 10 years. [6] Another study found that smoking can increased the risk of stroke about three times. [7]

Blood pressure is a factor that has contribtion for more than 12,7 million of incident stroke every year in the worldwide. The highest incident is among elder, African and also in Asian. [8] Hypertension is known as the most important risk factor for all type of stroke. ([9], [10]) Higher blood pressure increase the risk of stroke, [11] because high blood pressure correlate with higher incidence of atherosclerotic disease. [12]

The purpose of this study was to know the relation between smoking and hypertension in patients with stroke.

\section{MATERIAL AND Method}

This study is a cross sectional study, the sample was taken consecutively. The written informed consent was obtained from all subjects or their relatives (for comatose patients) who were admitted to Haji Adam Malik Hospital in North Sumatera, Medan, Indonesia during the study. Inclusion criteria were the presence of ischaemic stroke at the present hospital admission, age $>18$ years old, the neurological deficits were confirmed in all cases by computed tomography (CT) scan.

The state of smoking were classified into two categories: (1) nonsmokers (never smoked regularly or stopped regular smoking $\geq 5$ years ago) and (2) smokers (regular smoking within the last 5 years). Hypertension were classified into two categories: (1) not hypertensive (systolic blood pressure $\leq 130$ $\mathrm{mmHg}$ ), diastolic blood pressure $<90 \mathrm{mmHg}$ during hospitalization and did not use any antihypertensive agents), (2) hypertensive (systolic blood pressure $\geq$ $140 \mathrm{mmHg}$ ), diastolic blood pressure $\geq 90 \mathrm{mmHg}$ 
during hospitalization and use any anti hypertensive agents)

All sample matched with inclusion and exclusion criteria, demography data and others data were taken. Demography data was analized using descriptive statistic, to analize the relation, we used Chi-Square test. $\mathrm{P}$ value $<0,05$ was significant.

\section{RESULTS}

Of the 100 patients, the 68 patients had ischaemic stroke and 32 patients had haemorrhagic stroke, smoker 62 patients (45 ischaemic stroke, 17 haemorrhagic stroke), hypertension 79 patients (51 ischaemic stroke, 28 haemorrhagic stroke).

TABLE I

BASELINE CHARACTERISTIC OF THE PATIENTS

\begin{tabular}{|c|c|c|}
\hline Subjects & $\begin{array}{c}\text { Ischaemic } \\
\text { Stroke }\end{array}$ & $\begin{array}{l}\text { Haemorrhagic } \\
\text { Stroke }\end{array}$ \\
\hline $\begin{aligned} \text { Age: } & <50 \text { y.o. } \\
& >50 \text { y.o. }\end{aligned}$ & $\begin{array}{c}8 \\
60 \\
\end{array}$ & $\begin{array}{c}27 \\
5 \\
\end{array}$ \\
\hline $\begin{aligned} & \text { Sex: } \text { Male } \\
& \text { Female } \\
&\end{aligned}$ & $\begin{array}{l}41 \\
27 \\
\end{array}$ & $\begin{array}{l}22 \\
10 \\
\end{array}$ \\
\hline $\begin{array}{r}\text { Hypertension: Yes } \\
\text { No }\end{array}$ & $\begin{array}{l}51 \\
17 \\
\end{array}$ & $\begin{array}{c}28 \\
4 \\
\end{array}$ \\
\hline $\begin{array}{ll}\text { Smoking } & \text { Yes } \\
& \text { No }\end{array}$ & $\begin{array}{l}45 \\
23 \\
\end{array}$ & $\begin{array}{l}17 \\
15 \\
\end{array}$ \\
\hline
\end{tabular}

The differences in the characteristics between the patients with ischaemics stroke and haemorrhagics stroke are shown in table 1 . There were 8 patients of ischaemic stroke with age below 50 years old and 60 patients with age above 50 years old compare with 27 patients of haemorrhagic stroke with age below 50 years old and 5 patients with age above 50 years old. A total of 41 men had ischaemic stroke, 22 had haemorrhagic stroke, while 27 women had ischaemic stroke, 10 had haemorrhagic stroke.

TABLE II

PREVALENCE OF HYPERTENSION IN PATIENTS WITH STROKE

\begin{tabular}{|l|cc|}
\hline \multicolumn{1}{|c|}{ Subjects } & \multicolumn{2}{|c|}{ Hypertension } \\
& Yes & No \\
\hline Ischaemic Stroke & 51 & 17 \\
\hline Haemorrhagic Stroke & 28 & 4 \\
\hline
\end{tabular}

Hypertension was more prevalent in ischaemic than haemorrhagic stroke but the difference was not significant $(\mathrm{p}=0,152)$.
TABLE III

PREVALENCE OF SMOKING IN PATIENTS WITH STROKE

\begin{tabular}{|l|ll|}
\hline \multicolumn{1}{|c|}{ Subjects } & \multicolumn{2}{|c|}{ Smoking } \\
& Yes & No \\
\hline Ischaemic Stroke & 45 & 23 \\
\hline Haemorrhagic Stroke & 17 & 15 \\
\hline
\end{tabular}

Smoking was also more prevalent in ischaemic than haemorrhagic stroke but the difference was also not significant $(\mathrm{p}=0,210)$.

TABLE IV

RELATION BETWEEN SMOKING AND HYPERTENSION IN PATIENTS WITH STROKE

\begin{tabular}{|l|c|c|}
\hline \multicolumn{1}{|c|}{ Subjects } & Smoking & Hypertension \\
\hline Ischaemic Stroke & 45 & 51 \\
\hline Haemorrhagic Stroke & 17 & 28 \\
\hline
\end{tabular}

There is a significant relation between smoking and hypertension, $\mathrm{p}=0,001$.

\section{DisCUSSION}

This study found that, among 100 patients with stroke, 79 had hypertension as risk factor, among them, 51 had ischaemic troke, 28 had haemorrhagic stroke. Similar to other studies that also found hypertension as frequent risk factor. A study, consist of 5017 ischaemic stroke patients, found that $66,6 \%$ had hypertension as risk factor. [13] Other study found that, from 281 stroke patients with hypertension as risk factor, found $147(52,3 \%)$ had intracerebral haemorrhage, $128(45,5 \%)$ had stroke ischaemic, and $6(2,2 \%)$ had subarachnoid haemorrhage. [14] A study consist of 2337 patients with ischaemic stroke and 663 patients with haemorrhagic stroke, found that hypertension was the strongest risk factor for stroke. [15] Another case control study found thet hypertension had relation with stroke, and the relation was sifgnificant $(p<0,001)$ [16]. A study in Korea, found that the relative risk of intracerebral haemorrhage about $33,3 \%$ and subarachnoid haemorrhage about $4,98 \%$ in patients with hypertension grade 3 . [17]

Hypertension is the most frequent risk factor in stroke, more frequent in ischaemic stroke than in haemorrhagic stroke. [14]

Hypertension can accelerate the arherosclerotic process. [18] Atherosclerotic is the cause of death for more than half death in west countries, [19] its 
cause the most serious morbididy and mortality. [20] It is a slow progressive artery disease, produced by the thickness of tunica intima that caused by fibrous accumulation that gradually will narrowing the vessel lumen and caused trombus. [19] Atherosclerosis risk factors act at several points on this pathogenic pathway, such as the plaques generally cause clinical manifestations by producing flow-limiting stenoses that lead to tissue ischaemia, or by provoking thrombi that can interrupt blood flow locally or embolize and lodge in distal arteries. ([18], [21]) Hypertension it self can increase arterial wall extension, leading to disturbed repair processes and aneurysm formation. [21]. The weakness vessel wall, can be rupture and caused intracerebral haemorrhage. [19]

Study among 526 stroke cases, found that woman who live with a smoker husband can increased the risk and increased the prevalence of stroke by increasing the intensity and duration of smoker husband. [22] An acute increase in blood pressure and heart rate can be caused by smoking, because the nicotine acts as an adrenergic agonist that mediating local and systemic cathecolamine release. [5]

A cross sectional study among 91 stroke patients, consist of 71 active smoker and 41 stop smoking, the insident of ischaemic stroke $(n=46)$ higher than haemorrhagic stroke $(n=42)$. [14] In our study we found that among 62 patients of active smoker, the incidence of ischaemic stroke $(n=45)$ also higher than haemorrhagic stroke $(n=17)$.

Tobacco caused disease that responsible for death in higher income countries such as United States. [23] Globally, prevalent smoker higher between aged 18 and 44 years old and decreased dramatically after aged 65 years old, maybe because the disease has correlation with smoking. [6]

Insident of ischaemic stroke are higher than haemorrhagic stroke bacause smoking can decrease cerebral blood flow, that can increase the stroke risk by decelerate the flow or static phenomenon. [14]

Carboxy haemoglobinemia also increasing agregation of platelet, fibrinogen level, decreasing HDL level, and direct toxic effect from 1,3butadiena compound, accelerate the aterosklerostic in animal. Tobacco smoke also correlate with aterosklerotic development that measured by ultrasound at artery carotid wall, early artery damage in endothelium dilatation brachialis artery. The incidence of stroke increased in population which exposed to tobacco smoke with atherogenesis process. [6]

Our study has several limitation. First the study enrolled hospital based stroke patients rather than patients from a community based general population. Secondly, this study did not collect data on others several major risk factors such as diabetes mellitus, dyslipidemia, and cardiovascular disease.

\section{CONCLUSIONS}

Significant relationship between smoking and hypertension might be because both of its have an important role in developing of atherosclerotic vascular disease.

\section{ACKNOWLEDGMENT}

The authors gratefully that the present research is supported by Ministry of Research and Technology and Higher Education Republic Indonesia.The support is under the research grant Dana Non PNBP Penelitian Bidang Keunggulan Akademik (Talenta) University of Sumatera Utara of year 2016.

\section{REFERENCES}

[1] Sacco, RL, Kasner, SE, Broderick, JP, Caplan, LR, Connors, JJ, Culebras, A, et al. AHA/ASA Expert Consensus Document an Updated Definition of Stroke for the 21st Century a Statement for the Healthcare Professionals from the American Heart Association/ American Stroke Association. Stroke. 2013; 44: 2064-89

[2] Caplan, LR. Caplan's Stroke: A Clinical Approach. $3^{\text {rd }}$ ed. Butterworth-Heineman. Boston. 2009.

[3] Goldstein, LB, Adam, R, Albert, MJ, Appel, LJ, Brass, LM. Bushnell, CD, et al. Primary Prevention of Ischemic Stroke: A Guideline from the American Heart Association / American Stroke Association Council. Stroke. 2006; 37: 1583-633.

[4] Riset Kesehatan Dasar (RISKESDAS). Badan Penelitian dan Pengembangan Kesehatan Kementrian Kesehatan RI. 2013: 1-268

[5] Kim D. E, Lee K.B, Jang I.M, Roh H, Ahn M.Y, Lee J. Association of cigarette smoking with intracranial atherosclerosisin the patients withacute ischaemic stroke. Clinical Neurology and Neurosurgery. 2012; 114: 1243-1247.

[6] Shah, RS, Cole, JW. Smoking and Stroke: The More You Smoke The More You Stroke', Expert Review of Cardiovascular Therapy 2010: 8 (7): 917-32.

[7] Indira Y, Muralidhar M.V, Munisekhar K. Role of Smoking and Alcoholism In Cerebrovascular Accidents. International Journal of Physiotherapy and Research. 2014; 2(3):530-536.

[8] Magistris F, Bazak S, Martin J. Intracerebral Hemorrhage: Patophysiology, Diagnosis and Management. Clinical Review MUMJ. 2013; 10(1): 15-22.

[9] Khan J, Rehman A.U, Shah A.A, Jielani A. Frequency of Hypertension in Stroke Patients Presenting at Ayub Teaching Hospital. J Ayub Med Coll Abbottabad 2006; 18(1):1-3. 
[10] Fahimfar N, Khalili D, Mohebi R, Azizi F, Hadaegh F. Risk Factors For Ischaemic Stroke; Results From 9 years of Follow Up In A Population Based Cohort of Iran. BMC Neurology. 2012; 12:117.

[11] Onysko, J, Maxwell, C, Eliasziw, M, Zhang, JX, Johansen, H, Campbell, NR. Large Increases in Hypertension Diagnosis and Treatment in Canada After a Healthcare Proffesional. Stroke. 2006; 43: 853-60.

[12] Air, EL, Kissela, BM. Diabetes, the Metabolic Syndrome, and Ischemic Stroke Epidemiology and Possible Mechanism. Diabetes Care. 2007. vol. 30, no. 12, pp. 3131-40.

[13] Grau A.J, Weimar C, Buggle F, Heinrich A, Goertler M, Neumier S, et al. Risk Factors, Outcome, and reatment in Subtypes of Ischaemic Stroke. Stroke. 2001; 32: 2559-66

[14] Lohano, AK, Samie, A, Siayal, NN. Frequency of Stroke In Hypertensive Patients. Professional Medical Journal. 2014; 21 (3): 484-8.

[15] O’Donnell M.J, Xavier D, Liu L, Zhang H, Chin S.L, Melacini P.R, et al. Risk factprs for ischaemic and intracerebral hemorrhagic stroke in 22 countries (the INTERSTROKE study): a case-control study. Lancet. 2010;376:112-23.

[16] Sorganvy V, Kulkarni M.S, Kadeli D, Atherga S. Risk Factor For Stroke: A Case Control Study. Int J Cur Res Rev. 2014;06(03):46-52.

[17] Suh, II, Jee, HS, Kim, HC, Nam, CM, Kim, S, Appel, LJ. Low serum Cholesterol and Haemorrhagic Stroke in Men: Korea medical Insurance Corporation Study', The LANCET. 2001; 357: 922-5.

[18] Bilic i, Dzamonja G, Lusic I, Matijaca M, Caljkusic K. Risk Factor and Outcome Differences Between Ischaemic and Hemorrhagic Stroke. Acta Clin Croat (Original Scientific Paper). 2009; 48: 399403.

[19] Silbernagi, S. Heart and Circulation: Atherosclerosis. In: Silbernagi, S, Lang, F, Color of Atlas Patophysiology', Thieme Stuat Gard, New York, 2007. pp. 236-9.

[20] Hossmann K.A, Heiss W.D. Section 1 Chapter 1: Etiology, Patophysiology, and Imaging. Neuropathology and Patophysiology of Stroke. In: Brainin M, Heiss W.D (editors). Textbook of Stroke Medicine. New York: Cambridge University Press; 2010.p.1-77.

[21] Libby P, Ridker P.M, Hansson G.K. Progress and challenges in translating the biology of atherosclerosis. Nature. 2011; 473: 317323.

[22] Zhang, X, Shu, OX, Yang, G, Li, HL, Xiang YB, Gao YT, et al, 2005, 'Association of Passive Smoking by Husbands with Prevalence of Stroke among Chinese Woman Non Smokers', American Journal of Epidemiology. 2005: 161 (3): 213-8.

[23] Jha P, Phil M.D, Peto R, Global Effects of Smoking, of Quitting, and of Taxing Tobacco. The New England Journal of Medicine. 2014; 370:66-68. 